\title{
DÜBLIN
}

Technological University Dublin

ARROW@TU Dublin

\section{Making an Impact: New Directions for Arts and Humanities Research}

\author{
Ellen Hazelkorn \\ Technological University Dublin, ellen.hazelkorn@tudublin.ie
}

Follow this and additional works at: https://arrow.tudublin.ie/cserart

Part of the Arts and Humanities Commons, and the Higher Education Commons

\section{Recommended Citation \\ Hazelkorn, E. (2013) Making an impact: new directions for arts and humanities research. Arts and Humanities in Higher Education, 2013. Pre--print article. doi:10.1177/1474022214533891}

This Article is brought to you for free and open access by the Centre for Social and Educational Research at ARROW@TU Dublin. It has been accepted for inclusion in Articles by an authorized administrator of ARROW@TU Dublin. For more information, please contact arrow.admin@tudublin.ie, aisling.coyne@tudublin.ie, gerard.connolly@tudublin.ie.

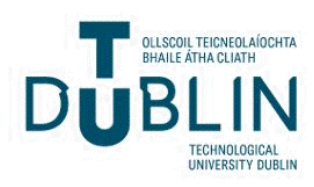




\title{
Making an impact: new directions for arts and humanities research ${ }^{1}$
}

\author{
Ellen Hazelkorn \\ Higher Education Policy Research Unit (HEPRU) \\ Dublin Institute of Technology \\ ellen.hazelkorn@dit.ie
}

\section{Abstract}

The severity of the global economic crisis has put the spotlight firmly on measuring academic and research performance and productivity, and assessing its contribution, value, impact and benefit. While traditionally, research output and impact was measured by peerpublications and citations, there is increased emphasis on a "market-driven approach", which favours the bio-, medical and technological sciences, and helped reinforce a disciplinary hierarchy in which arts and humanities research (A\&HR) has struggled for attention. This article charts the changing policy environment across Ireland, the Netherlands and Norway. It draws on evidence from the HERAVALUE project which studied how different stakeholders value arts and humanities research; almost 100 interviews were conducted with representatives from the academy, policymakers and civil society these three countries. Although the arts and culture have played a distinctive nation-forming role, and continue to do so, each country has adopted very different policy responses towards A\&HR.

\footnotetext{
${ }^{1}$ The author thanks Heravalue Project colleagues, Paul Benneworth and Magnus Gulbrandsen, and the two anonymous reviewers for their helpful comments and suggestions, albeit all errors are mine.
} 


\section{Understanding the policy context}

The arts and humanities are widely acknowledged as encouraging creativity and critical thinking, challenging orthodoxy, promoting self-expression and understanding of the human condition, and deepening awareness and appreciation of cultural distinctiveness, heritage and history. While the "culture wars" exposed tensions between world visions and value systems, and questioned different forms and formats of expression, there remains a belief that the arts - through inter alia drama, visual art, music and dance - and the humanities through inter alia literature, history and philosophy - have "transformative powers" (Belfiore and Bennett, 2007, p138) making vital and necessary societal contributions and underpinning democratic society (McCarthy et al, 2004; Bric, 1999, 7). Thus, they formed an enduring component of the academy since the establishment of the University of Bologna in 1088 as Europe's first degree-granting university. Over successive centuries, universities have helped satisfy a thirst for knowledge and provide the basis for resolving difficult problems.

This process has long been underway. Wilhelm von Humboldt (1767-1835, founder University of Berlin, 1810), influenced by the scientific revolution, saw the university as a training ground for professionals and advocated a closer nexus between teaching and research. In contrast, Cardinal John Henry Newman (1801-1890, inspiration for establishment of Catholic University, Ireland, 1852-58) one of the founding-fathers of the modern European university saw the university as the place for teaching universal knowledge. About the same time, the US Morrill Act (1862) established the Land Grant University; with a focus on the teaching of agriculture, science and engineering, these 
institutions sought to meet the needs of a changing social class structure rather than concentrate simply on classical studies.

This relationship was affirmed in 1945 with the publication of Science, The Endless Frontier by Vannevar Bush, Director of the US Office of Scientific Research and Development under Franklin D. Roosevelt. It emphasised the primacy of fundamental scientific research "and the application of that knowledge to practical purposes.... [as] without scientific progress no amount of achievement in other directions can insure our health, prosperity, and security as a nation in the modern world" (Bush, 1945). Over subsequent decades, knowledge has become recognised as the source of economic and political power, social and individual prosperity, and globalized capital accumulation. Because higher education (HE) and university-based research plays a fundamental role in creating knowledge, they have received increasing policy attention and public investment.

In this construct, knowledge gains legitimacy and value through its utility. Academic research is no longer solely the pursuit of individual intellectual curiosity but is driven by national priorities tied to strategies of economic growth and competitiveness. Its importance derives primarily through translation of knowledge into new products and services; "knowledge is defined as intellectual property (IP) that has commercial value" that "can be realized, in turn creating economic value and thus economic growth" (Robertson, 2008: 5). This correlation underpinned investment in "academic capital" (Slaughter and Leslie, 1997), sealing a "social contract" between the taxpayer, structured government financing and the research community, and generating a wider debate about social value (Belfiore and Bennett, 2007, p135). In the immediate aftermath of the global financial crisis (2008), and enduring recession across Europe, this instrumentalist environment has created 
a disciplinary hierarchy in which arts and humanities research (A\&HR) struggle for recognition and appreciation, under pressure to demonstrate value and relevance.

This article charts the evolving $\mathrm{HE}$ and research policy landscape across Ireland, the Netherlands and Norway, with implications for A\&HR. ${ }^{2}$ There are three main sections: the first part considers general policy trends which have seen a shift from valuing intellectual pursuits-for-their-own-sake to measuring research outcomes, impact and relevance; the second part provides short vignettes summarising and comparing the nuanced yet significant policy differences across the three countries; and the final part discusses the implications of these different approaches. For example, although arts and culture have played a distinctive nation-forming role, and continue to do so, each country has adopted very different policy responses towards $A \& H R$. To some extent these differences can be explained in terms of the immediacy of the economic crisis and its distinctive impact albeit these variances may reflect more profound differences in how research is seen to contribute to a knowledge society vs. a knowledge economy. It may also stem from a genuine uncertainty as to what policies work best to achieve balanced objectives. Given these tensions, how can arts and humanities researchers contribute to a better understanding of A\&HR's potential?

\footnotetext{
${ }^{2}$ It draws on the HERAVALUE project which studied how different stakeholders value A\&HR; almost 100 interviews were conducted with representatives from the academy, policymakers and civil society in these countries.
} 


\section{Shifts in the underlying environment for research policy}

\section{i. Impact and growing pressures for accountability}

Castells (1994, 1996) and Slaughter and Leslie (1997) contend that globalization has transformed discovery from an intellectual pursuit into an economic commodity as nations increasingly compete on the basis of their knowledge and innovation systems. This shift has highlighted the significance of investment in human capital and knowledge production making "high quality tertiary education more important than ever before" (Santiago, 2008, p. 13). The EU has similarly placed HE at the core of its research-innovation eco-system (European Commission, 2005). Today, most national policies reflect these same dynamics, such as the Irish Innovation Taskforce which stated (2010, p3): "Knowledge is the currency of the innovation economy and the education system is pivotal in making innovation happen".

Because HE plays a fundamental role in creating global competitive advantage, the performance of higher education matters to governments, who seek to maximise "capacity and performance within the global landscape" and optimise the "benefits ... back home" (Marginson and van der Wende, 2007, p17). This manifests itself in two ways. First, government adoption of new public management (NPM) techniques, twinned with neoliberal pressures and tendencies, has led to escalating demands for greater transparency and accountability alongside requirements for value-for-money and return-on(public)investment, especially relating to $\mathrm{HE}$ and university-based research (Ferlie et al, 2008, Molas Gallart, this issue). The other trigger has been the emergence of global rankings, which has placed quality assessment within a wider comparative and international framework (Hazelkorn, 2011). This policy shift is evident in the EU's modernisation agenda: 
Universities should be funded more for what they do than for what they are, by focusing funding on relevant outputs rather than inputs, ... Competitive funding should be based on institutional evaluation systems and on diversified performance indicators with clearly defined targets and indicators supported by international benchmarking (European Commission, 2006).

As the "knowledge economy" paradigm has strengthened and the economic-outlook has remained difficult, there has been increasing emphasis on this market-oriented approach (Hazelkorn, 2012a, 2012b).

Changes are evident across both teaching and learning, and research (Saunders et al, 2011). For research - the subject of this article - alongside an intensification of evaluation, assessment and auditing, there has been a growing emphasis on the translation of "ideas into income". Once policy seeks to promote knowledge with value and impact beyond the academy, there are implications for disciplines and fields of study, scholarly practice, and the choice of research projects: what research is being undertaken, what should be funded, how it is managed, how it is evaluated and measured, and by whom. Peer review, an academic cornerstone, undertaken on a collegial basis, has become formalised at both institutional and national level (Hicks, 2008). Dissemination practices within scientific communities through journals and conferences have been augmented or replaced by concrete measures of impact, benefit and relevance beyond scientific communities, often indicated by patents, licenses and start-up companies or impact statements. End-user or stakeholder esteem is being called upon/used to verify value.

These developments mark a transformation from regarding discovery as laying the basis for a civilized society to being first and foremost an economic investment. All disciplines are 
being asked to demonstrate what they do and its attendant public value. Rather than focusing on outcomes (e.g. level of performance or achievement including contribution to the advancement of scientific-scholarly knowledge), the emphasis is now on impact and benefit (e.g. contribution to the economy, and for society, culture and the environment). This reflects a rebalancing between: i) researcher curiosity vs. alignment with national priorities; ii) funding excellence-wherever-it-exists vs. strengthening capability or building scale; iii) encouraging new and emerging fields vs. prioritising existing strengths; and iv) valuing all disciplines vs. emphasizing those most able to create economic value.

Scientists have their own grumbles with this approach but this is a process which more easily favours the physical, life, and medical sciences. In contrast, arts and humanities researchers have often felt threatened by this process (see Belfiore, this issue). Their traditional methodology has often involved an intellectual, creative or speculative process of inquiry rather than what Crossick $(2006$, p2) caricatures as concern with the "'widget economy', in which a university research team develops a widget, patents it and transfers it out to industrial enterprise" (see Benneworth, this issue). Depending upon how governments and funding agencies react to these changes, they can represent a significant challenge for national arts and humanities research communities. The next section of this paper looks at the experience within three quite different national contexts.

\section{ii. New challenges for arts and humanities research?}

While there is differing emphasis on the importance of different disciplines, the arts and humanities have long had a societal mission in the certain belief that society can only benefit from the pursuit of knowledge and the scholarship which they generate. Today, much of that certainty faces challenges from the dominant "knowledge economy" policy 
paradigm, with its strong focus on "measurable 'impacts" (Belfiore and Bennett, 2007, p135). As nations prioritise economic recovery and "highly applied skills suited to profitmaking" and employability, there is a move to "cut away all useless things in order to stay competitive in the global market" (Nussbaum, 2010: 2). This raises the question of what are the effects of these pressures on arts and humanities research policies and activities, and whether these disciplines are unfairly disadvantaged by this shift of policy emphasis.

Human capital theory, which has underpinned most policy developments over recent decades, tends to see people primarily as economic entities (Becker, 1964, 1993). In contrast, Bourdieu (1986), broadening out the framework, argued that human capital is a more dynamic concept, including cultural capital, social capital, economic capital, and symbolic capital; "It is in fact impossible to account for the structure and functioning of the social world unless one reintroduces capital in all its forms and not solely in the one form recognized by economic theory." Arguably, tensions between these two models of the "structure and functioning" of the social and economic world lie at the heart of the policy tensions illuminated above. This, in turn, is reflected in the debate around research outlets, outputs, outcomes and impact, and how that is valued, assessed, measured and funded.

The abovementioned rebalancing factors have transformed the policy imperatives around research. Concerns about value-for-money and return-on-(public) investment have led to greater government steerage of the research system. The public and policy community has become less tolerant of self-proclamation or arguments of "intrinsic" value. All research is under the spotlight but A\&HR has felt special pressure because the policy questions challenge many disciplinary assumptions of this self-evident social value. This section looks briefly at the policy environment in the three HERAVALUE countries. 


\section{Comparing the policy dynamics of different national settings}

\section{Ireland $^{3}$}

\section{i. Policy overview}

Over the centuries, the arts and humanities have produced a reservoir of cultural artefacts and practices which framed an understanding of Ireland's colonial history. Irish language, music, dance, literature, poetry and history were central to the school curricula, defining the new state to itself and the outside world. However, despite this rich heritage, the state founded in 1922 viewed the arts with a mixture of suspicion, caution and paternalism. Censorship was enforced along with economic protectionism, justifiable in the context of the 1930s and WW2, but it gave rise to a sense of "cultural isolationism" and "intellectual malaise", all the more credible given the country's island status. Over the following decades, in the public sphere, Irish culture was used to "stem the flood-tide of commercial modernism" along with any ideas which challenged the prevailing catholic nationalism. As Irish artistic endeavours were limited, the vacuum was ironically filled by Anglo-American domination of popular culture (Fallon, 1998, p11; Hazelkorn, 2001).

In contrast, there was much greater leeway for elites. 1940 saw the establishment of the Dublin Institute for Advanced Studies encompassing a School of Celtic Studies and a School of Theoretical Physics, with a School of Cosmic Studies later established in 1947. Perhaps because of this positioning of the humanities within this somewhat rarefied environment, a classicist orientation dominated culture-specific fields and the academy, leaving a gap

\footnotetext{
${ }^{3}$ This section draws on Hazelkorn et al, 2012.
} 
between the popular notion of Ireland as a haven for the arts and humanities, and the reality. This remained the situation until the appointment of the first minister for the Arts, Culture and the Gaeltacht (Ireland's Irish-speaking regions) in 1993 and publication of The Employment and Economic Significance of the Cultural Industries in Ireland (Coopers and Lybrand, 1994) which took the arts down from the "high culture" shelf into the heartland of public policy: economic growth and employment.

This (re)orientation was in line with the state's determination to establish Ireland as a modern, advanced economy, a determination which acquired greater intensity as the benefits of the information society began to dominate policy discourse across Europe (Bangemann, 1994). With the adoption of the 2000 EU Lisbon Strategy, the phrase "knowledge society" entered official parlance; the production of new knowledge and knowledge management became core to economic growth (Harpur, 2010: 77), raising the profile of STEM research.

The Programme for Research in Third Level Institutions (PRTLI) was introduced in 1998, followed by Science Foundation Ireland (SFI) in 2000. While PRTLI supported research across the humanities, science, technology and social science, SFI invested in biotechnology, ICT and energy. Together with the Irish Research Council for Humanities and Social Science (IRCHSS) and the Irish Research Council for Science, Engineering and Technology (IRCSET), both created in 2001 under the auspices of the Higher Education Authority (HEA), they grew research capacity and capability. Prior to 2000, Ireland had no national research policy, investment strategy or noteworthy international reputation in scientific research. By 2009 , it ranked $8^{\text {th }}$ on the impact of research publications within a group of 20 comparator countries, and $8 \mathrm{HEls}$ ranked in the top 500 globally in the QS World University Rankings. 
However, even during this golden age, Ireland was not investing as intensively as OECD and EU peers. When the 2008 global financial crisis hit, an already delicate position was further weakened.

In response, there has been greater government steering of research priorities and funding criteria. The 2011 Research Prioritisation Exercise replaced encouragement of curiosityinspired research and excellence-wherever-it-exists with a "more top-down, targeted approach" focused around fourteen priority areas linked to industrial sectors (Forfás, 2012, p8); primacy in choosing these priorities was given to research relevance, job creation and innovation.

\section{ii. Arts and humanities research}

This changing policy focus marked the HEA's declining influence on research policy. Responsibility for PRTLI was transferred to the Department of Jobs, Enterprise and Innovation, and Science Foundation Ireland's (SFI) became the principal funding agency. In 2012, IRCHSS and IRCSET merged forming the Irish Research Council (IRC). This left no dedicated agency for A\&HR (or the social sciences), a gap which the newly-formed Irish Humanities Alliance sought to fill, albeit as a lobby group. Indeed, no policy attention has been given to A\&HR since publication of Playing To Our Strengths (HEA, 2010).

Overall research funding, as a percentage of GDP, has remained relatively stable despite an initial sharp decline in 2009; however, actual funding has fallen back to 2002 levels. Spending on the humanities (a separate figure for the arts is not available) which had grown under PRTLI has fallen since 2008 to approx. $4 \%$ of all HE R\&D funding (HERD) of which $82 \%$ comes from the government (direct and indirect); this contrasts with an average $7.7 \%$ over the previous decade. Another challenge is the nature of the research undertaken; while the 
actual number of researchers is much smaller than other disciplines, salary costs comprise $85 \%$ of total costs compared with engineering and technology or the natural sciences where salaries represents less than $60 \%$, and only $2 \%$ being spent on capital. Almost $90 \%$ of humanities research is classified as "basic" (Hazelkorn et al, 2013), which poses particular difficulties at a time when overall policy focus is on application-focused research. The Minister of State for Research and Innovation has sought to re-assure researchers saying no "scientific discipline" will be excluded although this may depend upon interpretation of the word "scientific" (Ahlstrom, 2013).

\section{Netherlands ${ }^{4}$}

\section{i. Policy overview}

The arts and humanities have played a prominent role in defining the Dutch nation and its people. Since the sixteenth century, there has been a strong tradition of independence. A combination of the limited global reach of the Dutch language, plus its majority Calvinist faith and mercantilist economy, manifested themselves in the Netherlands' proclivity for religious and intellectual openness and tolerance. Outward looking and international (in terms of trade rather than imperial conquest) for much of its modern history, the country presents a unique situation where the tensions between arts and humanities, STEM disciplines, and the pressures of innovation and the market are less pronounced than elsewhere.

\footnotetext{
${ }^{4}$ This section draws on Benneworth, 2012.
} 
In 1960, the first Higher Education Act was introduced, granting authority to the Dutch government to intervene in $\mathrm{HE}$ as it became increasingly apparent that education and research were important policy areas. During the 1970s, focus was directed to four goals: rationalization, democratization, integration and differentiation. This saw passage of a new Higher Education law (1970) altering the administrative constitution of universities, away from a traditional senate-based model of professors towards a central and faculty-led executive structure. Further developments came in 1975 with the Nota Wetenschapsbeleid, (science policy white paper), which sought to rationalize funding for universities and ensure research had societal relevance. A further white paper, the Nota Innovatie (1980) (Innovation White Paper) emphasized the importance and desirability of innovation. This was an attempt at the policy level to draw connections between research and the business sector. Interestingly, it did so by noting "technological problems are not purely technological, but rely also on social and organizational changes, and in particular the ways in which social groups react to technological change" (Benneworth et al., 2013: 34). This illustrates awareness that although STEM is the driver of innovation, this cannot occur in isolation from wider social and cultural concerns.

In 2010, the government identified nine "Top Sectors" in which the Netherlands was strong, and could be further developed which included the creative industry. These sectors emerged from a tradition of sectoral intervention dating back to 1982 (Velzing, 2013), and whilst the precise number and definition of these sectors has varied over the preceding three decades, there has been a remarkable consistency on the focus on key technologies of importance to the Dutch economy. This reflected the view that maintaining prosperity necessitated innovation and education, embracing a greener economy, and evidence of greater social and economic impact from publicly-funded research. 


\section{ii. Arts and humanities research}

Two organizations are responsible for publicly-funded research in the Netherlands: the Royal Netherlands Academy of Arts and Sciences (KNAW), and Netherlands Organisation for Scientific Research (NWO). The overall research landscape is, however, more complicated, with many organizations playing multiple roles with overlapping interests and responsibilities. Total research funding as a percentage of GDP has declined from a height of $1.93 \%$ in 2004 to $1.83 \%$ today (Eurostat, 2013).

KNAW advises the government and parliament on policy direction for scientific research, and supports research institutes(as well as having a separate Academicians section), of which ten are active in the humanities and social sciences. NWO is an independent administrative body and funding agency of the Department of Education, Culture and Science (OCW); it has established a number of advisory councils in every field of scientific study, including a Council for the Humanities. Two NWO Research Institutes conduct research in the social sciences. Its 2011-2014 strategy includes a specific theme relevant to the humanities: cultural and societal dynamics. The intention is to strengthen non-thematic or basic research, and investment in thematic or innovative research, through EU Horizon 2020 projects. Support for thematic programmes and new coalitions around Culture and Identity is anticipated, including research facilitated through HERA (ERA-net for the Humanities). A new process for evaluating university-based research has been developed which includes, in addition to peer-review, other qualitative methodologies which enable humanities research to be evaluated on its own terms.

The value and impact of humanities and cultural research has been a continuing focal point of discussion - a testament to its importance. From the early 1970s, "the Dutch government 
sought to address a deep-seated crisis of its own legitimacy by reforming the public sector to be more business-like." While "this has consistently worked against the humanities in universities", they have nonetheless continued to "benefit from a high public valuation in the most general terms" (Benneworth, 2012, p6) which may have acted as a bulwark against threats to continued support given to A\&HR. An important principle of the Dutch model of HE is the concept of parity of institutions (Benneworth, 2012, p52), a horizontal model of disciplinary and institutional equivalence, with high levels of institutional autonomy in return for equal treatment from government. This is manifested in that the humanities are funded as per the sciences, with similar resources, organizational structures and research infrastructure.

\section{Norway $^{5}$}

\section{i. Policy overview}

Even before independence in 1905, Norway had a strong cultural identity forged by its artists, musicians, and writers, illustrating that even within the socio-political sphere-ofinfluence of Denmark and Sweden, a unique Norwegian culture could thrive. This distinctiveness is evident in how Norway has developed its HE and research.

The University of Oslo was founded in 1811, succeeding the Royal Norwegian Society of Sciences in 1760. A number of other institutions followed but it was not until independence that a dedicated education and research infrastructure emerged. After WW2, universities

\footnotetext{
${ }^{5}$ This section draws Gulbrandsen and Aanstad, 2013.
} 
were strengthened through increased funding (e.g. Oslo, Trondheim), change in status (e.g. Bergen 1946 became a university; Troms $\varnothing$ in 1968), and the establishment of a single research council in 1993.

From the mid-1960s, emphasis was given to creating an integrated system meeting the skill and professional needs required at regional and national level, by developing new kinds of educational institutions in rural areas plus upgrading secondary schools. Reforms in 2003 brought Norway into line with the Bologna process; in 2005, universities and university colleges were allowed to provide education and conduct research, as well as academic and artistic development work at the appropriate international level. Arts institutions are generally much younger, although the Norwegian Academy of Music has roots in the $19^{\text {th }}$ century.

Norway is a relatively newcomer in research and HE. The country's rural orientation partially explains its strong mission-oriented focus on practical goals and uses, and the absence of a tradition of fundamental research. It was a pioneer in scientifically-based studies of fish stocks and related areas such as ocean science and meteorology (Gulbrandsen and Nerdrum, 2009). Research institutes created after the 1940s concentrated on mission- and regional-oriented research in technology, natural science and social science. In contrast, A\&HR was supported and found primarily within HE.

Since the 1980s, the Norwegian research system has changed in line with developments in the other countries. Basic research funding has declined at the same time that emphasis has been placed on increasing external funding with a strong growth in thematically-bounded research council programmes. Accordingly, resources have been concentrated and aligned with nationally appointed target areas. Over the years, there has been strong growth in 
industrial research and development (R\&D), with increasing emphasis on the role of HE in society and on public science's contribution to creating new jobs and national and regional competitiveness (1980s), innovation (1990s) and commercialisation (2000s). Science parks and other mechanisms for increased university-society interaction were established after the mid-1980s.

The humanities and social sciences are generally viewed by policymakers as important for societal development and change. This is especially true for the social sciences, which continue to enjoy a strong endorsement due to a widely shared belief that with more knowledge and research the school and health systems, and welfare state more generally, will work better. In the last decade, research funding has risen significantly, accompanied by a swing towards basic research (Gulbrandsen and Nerdrum 2009).

\section{ii. $\quad$ Arts and humanities research}

The national classification system for scientific disciplines, developed by the Norwegian Association of HEls, provides a taxonomy of fields comprising the humanities. While the status of practice-based disciplines or arts research is not defined as a scientific discipline in the same way, there is less formal recognition of such research. The definition used is from a 2007 report, Vekt på kunstnerisk utviklingsarbeid (KU), which says "artistic research covers artistic processes leading up to a publicly available artistic product. The process may include explicit reflection on the development and presentation of the artistic product" (quoted in Gulbrandsen and Aanstad, 2013, p17; Malterud, 2012, p8). It recognises a synergy loop between artistic practice and theoretical self-interrogation.

Norway has only one research council, the Research Council of Norway (RCN), which also has an innovation agency remit. Under the "sector principle", each government ministry is 
responsible for research within its own field, e.g. the Ministry of Culture is responsible for $R \& D$ relating to the cultural sector, and is currently defining a strategy for research in the cultural realm. While this facilitates $A \& H R$, it does mean greater emphasis on discrete strategies rather than overall co-ordination although responsibility for education and research policy is held by the Ministry of Education and Research. The latter defines national research policies, and is also the largest funding agency and most importantly for A\&HR. There are two kinds of funding: the basic grant which has remained relatively stable over time, and competitive performance-based funding. HEls are "rewarded for attaining research council and European Union funding, and they are rewarded for scientific publications. The latter has raised a lot of controversy, not least from representatives from the humanities" (Gulbrandsen and Aanstad, 2013: 45).

The shift towards innovation and application has meant equal distribution between applied and basic research depending upon the discipline. Performance-based funding has been controversial. However, there is recognition that the distinctiveness and breadth of A\&HR outputs requires some self-reporting rather than over-reliance on quantitative measurements or international databases. Arts institutions operate within the overall funding system, receiving basic funding from the Ministry of Education and Research, but are separate from performance-based formula suggesting strong awareness that the arts are qualitatively different even to the humanities.

\section{Discussion}

The arts and humanities have played a significant role in cultural identity and nation-state formation in all three countries. For Ireland, language, literature and music framed and interpreted its colonial and post-colonial experience, while for Norway and the Netherlands 
culture and language helped formulate their distinctive relationship with neighbours and their independence. Looking at these shared experiences could suggest on-going similarities but considerable divergence has occurred as the vignettes suggest.

Ireland experienced a dramatic and sudden economic collapse, while Norway was protected by its rich oil reserves and the Netherlands by its stronger economic base. These differences in the underlying strength/weakness of the economy influence attitudes. All countries have placed increasing emphasis on public value, research relevance, and innovation, but Ireland and the Netherlands occupy opposite ends of a spectrum. Ireland has a strong industrial focus and the Netherlands support basic research across all disciplines; Norway sits in the middle. In contrast to Ireland which has displayed a somewhat ambiguous relationship to intellectual curiosity, both Norway and the Netherlands have an enduring commitment to arts-based research and in recent years have strengthened this with specific reference to the cultural industries and culture-based research. With the exception of PRTLI which funded significant research initiatives and capital developments in A\&HR, this has not been a recognised focus of Irish research policy despite the aforementioned 1994 report on the cultural industries and government usage of culture to help rebuild its national reputation after the economic collapse. In this respect, a distinction is made between A\&HR, and arts and culture, the latter receiving beneficial funding under various headings.

These differences resonate in how research is valued and assessed. There is currently no national assessment of research in Ireland, although there is a biennial inventory. Both Norway and the Netherlands have formal processes, the former quantitative and the latter qualitative, albeit in both jurisdictions, the distinctive practices and methodologies of the arts and humanities are recognised (see Table 1). The most sophisticated approach is 
KNAW's Quality Indicators for Research in the Humanities, to operate 2015-2021 (cf. RIA, 2009). Variances in environment and state behaviour help explain researcher responses. For example, the Research Council of Norway has engaged directly with the new policy agenda emphasising its contribution to climate, polar and petroleum research, with a focus on innovation (Metris-No, 2012), whereas Irish researchers have sought to defend their turf; O'Donnell (2011) suggests that this classicist approach may have contributed to them "becom[ing] isolated". 
Table 1 Comparison of Research Assessment Methods

\begin{tabular}{|c|c|c|c|c|c|c|c|c|c|}
\hline Country & Name & System Author & Methodology & A\&H Element & $\begin{array}{l}\text { Linked to } \\
\text { Resource } \\
\text { Allocation }\end{array}$ & $\begin{array}{c}\text { Expert/Peer } \\
\text { Review }\end{array}$ & $\begin{array}{c}\text { Internal or } \\
\text { External } \\
\text { Review }\end{array}$ & $\begin{array}{l}\text { Unit of } \\
\text { Analysis }\end{array}$ & Timescale \\
\hline Ireland - Forfás & $\begin{array}{c}\text { Higher } \\
\text { Education } \\
\text { R\&D (HERD) } \\
\text { Survey }\end{array}$ & Forfás & Quantitative & No & Advisory & No & External & National & 2 Years \\
\hline Netherlands & $\begin{array}{c}\text { Standard } \\
\text { Evaluation } \\
\text { Protocol } \\
2009-2015\end{array}$ & $\begin{array}{l}\text { Royal Netherlands } \\
\text { Academy of Arts } \\
\text { and Sciences, } \\
\text { Association of } \\
\text { Universities in the } \\
\text { Netherlands, } \\
\text { Netherlands } \\
\text { Organisation for } \\
\text { Scientific } \\
\text { Research }\end{array}$ & Qualitative & Yes & No & Yes & Both & $\begin{array}{l}\text { Department \& } \\
\text { Institute }\end{array}$ & 6 Years \\
\hline Norway & $\begin{array}{c}\text { New Model } \\
\text { for Result } \\
\text { based } \\
\text { University } \\
\text { Research } \\
\text { Funding }\end{array}$ & $\begin{array}{c}\text { Norwegian } \\
\text { Research Council }\end{array}$ & Quantitative & No & Yes & No & External & $\begin{array}{l}\text { Department \& } \\
\text { Institute }\end{array}$ & 1 Year \\
\hline
\end{tabular}


There are various dimensions to these debates which underlie the perceived underappreciation of A\&HR. First, there is the sheer breath of the disciplinary base; A\&HR includes everything from the creative and performing arts to classics, history, literature, linguistics and jurisprudence. They "contribute to a constantly growing body of knowledge on human experience, agency, identity and expression, as constructed through language, literature, artefacts and performance" (Bakhshi et al, 2008, p1). While humanities scholars utilize archives and libraries, creative arts researchers engage in practice-led (alternatively: practice-based, studio-based or studio-led) methodologies (Biggs, 2007). The latter produces a collection of artefacts (e.g. paintings, sculpture, music composition, performances, etc.) often for exhibition or performance while the latter produces traditional academic texts.

Second, in contrast to science and technology, A\&HR practice is predominantly a curiosityinspired individual endeavour which does not easily lend itself to use-inspired team-based projects, traditional research outlets or assessment methodologies. Results cannot be simply codified into intellectual property (IP) or translated into new products and services which can make it difficult to demonstrate how A\&HR flows into society and the economy. This is because, in addition to books and book chapters, A\&HR produce maps, major art works or award-winning designs, policy documents and technical reports, television documentaries and radio programmes, exhibitions and cultural artefacts, and so on.

Third, to get around these difficulties, A\&HR often seeks refuge in "exceptionalism", relying on what Belfiore and Bennett (2007, p145-147) call the "art-for-art-sake" or intrinsic value argument, whereby the value "resides firmly in the aesthetic sphere". Subsequent misunderstandings may arise in the reluctance of scholars to engage in "writing-up" the 
intellectual and critical processes embedded in their practice, claiming the artefact or composition is itself research (Biggs, 2007). This leads to the perception that the work lacks academic rigour or that it is not research. Both may be true, but likewise both may be untrue.

Fourth, differences in practice can spill over into debilitating quarrels between disciplines, most commonly between scientists and non-scientists but occasionally between the arts and humanities (Griffin, 2006, p238-239). Closer inspection reveals disciplines share more in common than not. Social, lab and engineering sciences are equally practice-based, drawing on field work or experimentation to test theoretical propositions. Bollen et al's (2009) clickstream maps, based on nearly 1 billion scholarly user interactions, shows the extent to which humanities research contributes to the wider knowledge economy not just in terms of knowledge creation within its own fields but also in interactions with fields hitherto regarded as beyond its purview. Bod (2012) illustrates this dynamic with reference to the 6th century Indian linguist Panini whose grammar-formalism underpins discoveries in computational and digital humanities leading to advances in speech recognition and automatic translation, such Google Translate. Similar examples can be found, inter alia, in the discoveries of Field who created the nocturne during the $19^{\text {th }}$ century or Gray who is considered a pioneer of the modernist movement in design (Hazelkorn et al, 2012, pp99100).

Fifth, the flaw may lie in over-reliance on traditional perceptions of research emerging from a techno-science model. Rather than using a linear or single input-output model to calculate benefit, research creates a wider value in a more indirect and often oblique way (Benneworth, 2012). Traditional methodologies used for measuring the quantity and impact 
of research is via peer-reviewed journal articles and citation impact factors, but this is only the tip of the iceberg and misses the full story of arts and humanities valorisation (Dolan, 2008; Lesage, 2009). As Figure 1 illustrates, the range of outcomes and outlets is wider (below the red line) than articles, and impact can be felt through teaching (the primary purpose for university-based research), improvements to productivity and the quality of life, increased employment, informed public debate, policy change and social innovation, and so on.

Figure 1 Tip of the Iceberg? Research Outputs and Impacts

\begin{tabular}{|c|c|}
\hline - Journal articles & - Peer Esteem \\
\hline $\begin{array}{l}\text { - Book chapters } \\
\text { - Computer software and databases } \\
\text { - Conference publications } \\
\text { - Editing of major works } \\
\text { - Legal cases, maps } \\
\text { - Major art works } \\
\text { - Major works in production or } \\
\text { exhibition and/or award-winning } \\
\text { - design } \\
\text { - Patents or plant breeding rights } \\
\text { - Relicy documents or brief } \\
\text { - Tesearch or technical reports } \\
\text { - Transingl drawings, designs or } \\
\text { - Visual recordings }\end{array}$ & $\begin{array}{l}\text { - Impact on Teaching } \\
\text { - } \quad \text { Improved Productivity, Reduced } \\
\text { - } \quad \text { Impros } \\
\text { lifestyle } \\
\text { - Improving people's health and } \\
\text { - } \text { quality of life } \\
\text { - Increased employment } \\
\text { - } \quad \text { New approaches to social issues } \\
\text { - } \quad \text { New curriculum } \\
\text { - } \quad \text { Patents, Licenses } \\
\text { - } \quad \text { Policy change } \\
\text { - Social innovation } \\
\text { - Stakeholder esteem } \\
\text { - Stimulating creativity }\end{array}$ \\
\hline
\end{tabular}

Finally, policymakers and $A \& H$ researchers are not talking the same language. Policymakers perceive value and impact in market terms whereas scholars speak broadly in terms of offering "skills of intercultural communication and rhetoric...concerned with identityforming as well as identity-expressing meaning-making..." (Parker, 2007, p125; cf. Geoghegan-Quinn, 2013). While stakeholders interviewed for the HERAVALUE project were universal in their praise for A\&HR, some said it took too long for benefits to emerge, and 
there was often a disconnection with real life. They also urged A\&H researchers to learn from the sciences (and to some extent the social sciences) about how to tell stories which interest the public in order to "articulate better what they are doing and why it's important" (Hazelkorn et al, 2013; cf. IRCHSS, 2010). This includes putting "clearer stress on the links between teaching and research" (HEA, 2010, p13), and/or working out "how to make industry interested...there can also be huge potential for enabling research which can either respond to industry's needs in a task oriented way or product development way" (Donovan, 2012, p16).

\section{Conclusion: Implications for A\&HR, researchers and policymakers}

Responding to this challenge has provoked a dialogue with the public and within the A\&HR community. For Parker (2007, p126-127), the solution lies in emphasizing the unique perspective A\&HR can make to Europe, while McCarthy $(2004, x i)$ argues A\&HR should emphasize its contribution to "measurable benefits, such as economic growth and student learning" of value to all society while also "enrich[ing] people's lives". On the other hand, Peyraube (quoted in Griffith, 2006, p236; ALLEA, 2013; Griffin, 2006, p239) says A\&HR should link "questions of belief, myth and value [as] we have done in the past,...[with] areas such as the mediation of nanotechnologies, poverty, third-world debt reduction, the negotiation adjustments to climate change and so on..." Other opportunities come by aligning $A \& H R$ with computing and electronics, and underpinning the cultural industries (Hazelkorn, 2001).

As the three case studies illustrate, the techno-science research paradigm has dominated the conversation about the value and impact of research albeit the policy approach has not been uniform. Although the arts and culture have played a significant role in nation- 
formation and remain strong emblems of national identity in all three jurisdictions, $A \& H R$ has been treated quite differently. For the Netherlands and Norway, the arts and humanities have been praised because of the way in which they challenge popular dogma whereas the Irish example suggests a more equivocal support. For a large part of the $20^{\text {th }}$ century, the more dominant ideas and values were challenged in Ireland, the greater the level of censorship and isolation. A new era began to open up, in recent years, once research began to make itself relevant to the state's major project: economic modernisation. This tension was understandably less deterministic in the Netherlands and Norway which helps explain why the policy approaches have been so different.

Drawing on the HERAVALUE project, there is evidence of a genuine commitment to $A H \& R$, and that policymakers and the academy are inching towards a common language. There is also little doubt the on-going fiscal and economic crisis colours conversations about research across Europe, raising the bar and throwing down the gauntlet to researchers of all disciplines, but particularly to A\&HR. Policymakers face their own pressures according to a former British arts minister:

I know that Arts and Culture make a contribution to health, to education, to crime reduction, to strong communities, to the economy and to the nation's well-being but I don't always know how to evaluate it or describe it. We have to find a language and a way of describing its worth. It's the only way we'll secure the greater support we need (Estelle Morris quoted in Belfiore and Bennett, 2007, p136; cf. Belfiore, this issue).

Thus reassuringly, the problem may ultimately be a perceived rather than a real threat. In response to a plea for help in meeting the challenge for greater transparency, value-for- 
money and return-on-(public)investment this regard, there is a shared view that researchers of all hues should engage more directly and meaningfully in discussion about demonstrating public value. Reciprocally, governments must develop more inclusive research assessment processes, and the academy itself should review its own recruitment and promotion criteria. These developments may ultimately prompt a re-focusing of A\&HR not just in terms of agreeing the appropriate measurable outputs and widening understanding of value and impact but also in terms of new fields of inquiry, and a (re)alignment with societal and economic challenges.

\section{References}

Ahlstrom, D. (2013) "State funds for science to be based on merit". Irish Times, 7 January. Retrieved from

http://www.irishtimes.com/newspaper/ireland/2013/0107/1224328507515.html

ALLEA (2013) “Embedding the Social Sciences and Humanities in Horizon 2020", Retrieved from http://www.allea.org/Content/ALLEA/News/2013/2013-0228\%20ALLEA\%20Roadmap\%20on\%20Embedding\%20SSH\%20in\%20Horizon\%202020 final.p $\underline{\mathrm{df}}$

Bangemann, M. (1994) Report on Europe and the Global Information Society: Recommendations of the High-level Group on the Information Society to the Corfu European Council. Bulletin of the European Union, 2 (94).

Bakhshi, H., Schneider, P., and Walker, C. (2008) Arts and Humanities Research and Innovation. Bristol: AHRC.

Belfiore, E. and Bennett, O. (2007) "Rethinking the social impacts of the arts." International Journal of Cultural Policy, 13:2, 135-151. 
Becker, G.S. (1964, 1993, 3rd ed.). Human Capital: A Theoretical and Empirical Analysis, with Special Reference to Education. Chicago: University of Chicago Press

Benneworth, P. (2012) Thirty years of crisis? The disputed public value humanities research in the Netherlands 1982-2012. Unpublished Netherlands National Report, HERAVALUE.

Biggs, M. (2007) “Modelling Experiential Knowledge for Research”. In Mäkelä, M., and Routarinne, S. (Eds.) The Art of Research: Research Practices in Art and Design. Helsinki: University of Art and Design.

Bod, R. (2012) "How the Humanities Changed the World". HERAVALUE Symposium and Evidence Session. Amsterdam, 30 May.

Bollen, J., Van de Sompel, H., Hagberg, A., Bettencourt, L., Chute, R., Rodriguez, M.A., and Balakireva, L. (2009) “Clickstream Data Yields High-Resolution Maps of Science”, PLoS ONE, 4(3) [Internet]. Retrieved from http://dx.plos.org/10.1371/journal.pone.0004803

Bourdieu, P. (1986) "The Forms of Capital”, Retrieved from:

http://www.marxists.org/reference/subject/philosophy/works/fr/bourdieu-formscapital.htm

Bric, M. J. (1999) The Humanities and the Social Sciences: A Case for a Research Council. A Report to the Minister for Education and Science. Higher Education Authority, Dublin. Bush, V. (1945) Science the Endless Frontier. National Science Foundation, US. Retrieved from http://www.nsf.gov/od/lpa/nsf50/vbush1945.htm\#summary

Castells, M. (1994) “The University System: Engine of Development in the New World Economy". In Salmi, J. and Vespoor, A. M. (Eds) Revitalizing Higher Education, Pergamon, Oxford, 14-40. 
Castells, M. (1996) Rise of the Network Society, The Information Age: Economy, Society and Culture. Massachusetts: Blackwell Publishers.

Coopers and Lybrand (1994) The employment and economic significance of the cultural industries in Ireland. Dublin: Corporate Finance Service.

Crossick, G. (2006) "Knowledge transfer without widgets: the challenge of the creative economy", Lecture to the Royal Society of Arts, Leeds, UK. Retrieved from http://www.goldsmiths.ac.uk/warden/creative-economy.pdf

Dolan, C. (2008) Feasibility Study: The Evaluation and Benchmarking of Humanities Research in Europe. Humanities in the European Research Area (HERA). Retrieved from http://www.heranet.info/system/files/hera report evaluation and benchmarking of humanities research in europe.pdf Donovan, B. (2012) Quoted in RIA, Report on Dialogue on Research Funding. Retrieved from http://www.ria.ie/getmedia/0b1e34ba-c427-47e3-9d77-ba40e0e2719b/Royal-IrishAcademy-Report-on-Research-Dialogue.pdf.aspx.

European Commission (2005) Working Together for Growth and Jobs: A New Start for the Lisbon Strategy, Communication from President Barroso, COM(2005) 24 final, European Commission, Brussels. Retrieved from http://www.clubofrome.at/events/2006/brussels/files/lisbon-strategy-2005-cc.pdf European Commission (2006) Delivering on the Modernisation Agenda for Universities: Education, Research and Innovation, Communication to the Council and the European Parliament, (COM) 2006208 final, European Commission, Brussels. Retrieved from http://www.madrimasd.org/proyectoseuropeos/documentos/doc/education research and innovation.pdf 
Eurostat, 2013. Retrieved from

http://erawatch.jrc.ec.europa.eu/erawatch/opencms/system/modules/com.everis.erawatc h.template/pages/exportTypesToHtml.jsp?contentid=a740e07f-7d1b-11df-b939$\underline{53862385 \mathrm{bcfa} \& \text { country=Netherlands\&option }=\text { PDF }}$

Ferlie, E., Musselin, C. and Andresani, G. (2008) "The steering of higher education systems: a public management perspective". Higher Education, 56, 325-348.

Fallon, B. (1998) An Age of Innocence, Irish Culture 1930-1960. Dublin: Gill and Macmillan. Forfás (2012) Report of Research Prioritisation Steering Group. Dublin: Forfás. Retrieved from http://www.djei.ie/publications/science/2012/research prioritisation.pdf Geoghegan-Quinn, M. (2013) "Social sciences are a compass in demanding times". The Irish Times. 8 May. Retrieved from http://www.irishtimes.com/business/social-sciences-are-acompass-in-demanding-times-1.1385260

Griffin, G. (2006) “Balancing Agendas: Social Sciences and Humanities in Europe”, Arts and Humanities in Higher Education. 5(3), 219-241.

Gulbrandsen, M. and Aanstad, S. (2013) Arts and humanities research in Norwayperspectives on value, relevance and utility. Unpublished Norway National Report, HERAVALUE.

Gulbrandsen, M. and Nerdrum, L. (2009) “Public R\&D and industrial innovation in Norway: a historical perspective." In Fagerberg, J., Mowery, D.C. and Verspagen, B. (Eds.), Innovation, Path-Dependency and Policy: The Norwegian Case. Oxford: Oxford University Press, pp6188. 
Harpur, J. (2010) Innovation, Profit and the Common Good in Higher Education. The New Alchemy. London: Palgrave MacMillan.

Hazelkorn, E. (2001) “The Dynamics of Cultural Production in Ireland: Economic Strategy, Digital Technology and Public Policy Making". In Ernst, K., Halbertsma, M., Janssen, S., and Ijdens, T. (Eds.) Trends and Strategies in the Arts and Cultural Industries. Rotterdam: Barjesteh van Waalwijk van Doorn \& Co.'s .

Hazelkorn, E. (2011) Rankings and the Reshaping of Higher Education: The Battle for World Class Excellence. Basingstoke: Palgrave Macmillan.

Hazelkorn, E. (2012a) “Measuring Value: Societal Benefits of Research", Chronicle of Higher Education, 15 August 2012. Retrieved from http://chronicle.com/blogs/worldwise/measuring-value-societal-benefits-of$\underline{\text { research } / 30179}$ Hazelkorn, E. (2012b) “Measuring Value: University-Based Research and National Needs", Chronicle of Higher Education, 7 August 2012. Retrieved from http://chronicle.com/blogs/worldwise/measuring-the-value-of-university-based-researchpart-i/30149 Hazelkorn, E. (2013) “Europe Looks for Better Ways to Measure the Value of the Arts and Humanities", Chronicle of Higher Education, 10 January. Retrieved from http://chronicle.com/blogs/worldwise/europe-looks-for-better-ways-to-measure-the-valueof-the-arts-and-humanities/31413

Hazelkorn, E., Ryan, M., Gibson, A., and Ward. E. (2013) Recognising the Value of the Arts and Humanities in a Time of Austerity. Irish National Report, HERAVALUE. Higher Education 
Policy Research Unit (HEPRU), Dublin Institute of Technology. Retrieved from http://www.dit.ie/hepru

HEA (2010) Playing to Our Strengths. The Role of the Arts, Humanities and Social Sciences and Implications for Public Policy. Dublin: HEA. Retrieved from http://www.hea.ie/files/files/file/HEA\%20FAHSS\%20Report.pdf

Hicks, D. (2009) "Evolving regimes of multi-university research evaluation." Higher Education 57: 393-404.

Innovation Taskforce (2010) Innovation Ireland. Report of the Innovation Taskforce.

Government of Ireland, Dublin. Retrieved from http://www.enterprise-

ireland.com/en/About-Us/News/Report\%20of\%20the\%20innovation\%20task\%20force.pdf

IRCHSS (2010) Mosaic: A Celebration of Irish Research in the Humanities and Social Sciences Dublin.

Malterud, N. (2012) "Artistic research - necessary and challenging", Nordic Journal of Art and Research. Retrieved from http://www.khib.no/media/800946/Nina-Malterud-Artisticresearch-necessary-and-challenging.pdf

McCarthy, K. F., Ondaatje, E. H., Zakaras, L. and Brooks, A. (2004) Gifts of the Muse.

Reframing the Debate About the Benefits of the Arts. Santa Monica, CA: Rand Corporation. Marginson, S. and M. van der Wende (2007) Globalisation and Higher Education, OECD Education Working Papers No. 8. Paris: OECD.

Metris-NL (2012) “New SSH policy developments", Metris Report for the Netherlands. http://www.metrisnet.eu/metris/index.cfm/report/findByStructureAndCountry/28/70 
Metris-No (2012) “New SSH policy developments", Metris Report for Norway.

http://www.metrisnet.eu/metris/index.cfm/report/findByStructureAndCountry/28/81

Nussbaum, M. (2010) Not for Profit. Why Democracy Needs the Humanities. Princeton:

Princeton University Press.

O'Donnell, R. (2011) "Making the Case for the Role of Arts, Humanities and Social Sciences", HERAVALUE Seminar, Dublin.

Ó Riain, S. (2004) “State, Competition and Industrial Change in Ireland 1991-1999”. The Economic and Social Review 35 (1): 27-53.

RIA = Royal Irish Academy (2009) Developing Performance Indicators for the Humanities.

Dublin: RIA. Retrieved from http://www.ria.ie/getmedia/6154483b-3c09-438c-aeb139bcae62da32/KPI-in-the-Humanities-(Oct-2009)-Report.pdf.aspx

Robertson, S.L. (2008) “Producing Knowledge Economies: The World Bank, the KAM, Education and Development", Centre for Globalisation, Education and Societies, University of Bristol. Retrieved from

http://www.bris.ac.uk/education/people/academicStaff/eds/r/publications/19slr/

Santiago, P., K. Tremblay, E. Basri and E. Arnal (2008) Tertiary Education for the Knowledge Society, 2. Paris: OECD.

Saunders, M., Trowler, P. and Bamber, V. (2011) Reconceptualising Evaluation in Higher Education. The practice turn. Maidenhead: SRHE/Open University Press.

Slaughter, S. and L. Leslie (1997) Academic Capitalism. Politics, Policies and the Entrepreneurial University. Baltimore: Johns Hopkins University Press. 
Velzing, E. J. (2013) “Innovatiepolitiek - Een reconstructie van het innovatiebeleid van het ministerie van Economische Zaken van 1976 tot en met 2010", Unpublished Ph.D. thesis. Amsterdam: University of Amsterdam. 